\title{
Screening and Statistical Optimization of Physiochemical Parameters for the Production of Xylanases from Agro-Industrial Wastes
}

\author{
Mirza Baasit Ali1, Muhammad Irshad1, Zahid Anwar ${ }^{1 *}$, Mudassar Zafar1, \\ Muhammad Imran ${ }^{1,2}$ \\ ${ }^{1}$ Department of Biochemistry \& Molecular Biology, Faculty of Sciences, University of Gujrat, Gujrat, Pakistan \\ ${ }^{2}$ Institute of Biochemistry \& Biotechnology, University of Veterinary and Animal Sciences, Lahore, Pakistan \\ Email: ${ }^{2}$ zahid.anwar20@gmail.com
}

Received 18 January 2016; accepted 28 March 2016; published 31 March 2016

Copyright (C) 2016 by authors and Scientific Research Publishing Inc.

This work is licensed under the Creative Commons Attribution International License (CC BY). http://creativecommons.org/licenses/by/4.0/

\section{(c) (i) Open Access}

\begin{abstract}
Xylanases are mostly produced through submerged fermentation; nonetheless solid-state fermentation has increased profound attention and consideration of scholars having high conversion level biomass to energy conservation. This study depicted the purification of xylanases and their possible utilization in industry. The present study was carried out to examine the culture influence of fungal strain Fomes fomentarius ( $F$. fomentarius) using different agro-industrial residues (wheat straw, rice husk, sugarcane bagasse and siris pods). F. fomentarius showed maximum enzyme production after $72 \mathrm{~h}$ of fermentation, when grown on wheat straw in solid state fermentation process while maximum activity showed on pH 6.0 at $30^{\circ} \mathrm{C}$. The other parameters optimized by statistical design (RSM) showed maximum xylanase activity (146 $\pm 8 \mathrm{IU} / \mathrm{mL})$ at $65 \%$ moisture content, $4 \mathrm{~mL}$ inoculums size, $175 \mathrm{mg}$ Ammonium sulphate, $200 \mathrm{mg}$ Calcium carbonate and 1.4 grams of glucose. Xylanase was salted out at $60 \%$ ammonium sulphate concentration and enzyme was further purified by Sephadex G-100 gel filtration chromatography with 2.2 fold increase in activity. The purified xylanase from $F$. fomentarius had optimum pH 6.0 and $40^{\circ} \mathrm{C}$. Xylanase showed higher specificity for oat spelt xylan with kinetic constants $\mathrm{Km} 1.25 \mathrm{mg} / \mathrm{mL}$ and $V_{\max } 54 \mathrm{mM} / \mathrm{min}$. Xylanases have an industrial important enzyme used extensively in food, feed and paper industry.
\end{abstract}

\section{Keywords}

Xylanases, Wheat Straw, Enzyme Kinetics, F. fomentarius, Siris Pods

\footnotetext{
*Corresponding author.
}

How to cite this paper: Ali, M.B., Irshad, M., Anwar, Z., Zafar, M. and Imran, M. (2016) Screening and Statistical Optimization of Physiochemical Parameters for the Production of Xylanases from Agro-Industrial Wastes. Advances in Enzyme Research, 4, 20-33. http://dx.doi.org/10.4236/aer.2016.41003 


\section{Introduction}

Lignocellulosic material is one of the most abundant bio-polymer in nature and it has three major constituents; one of them is the hemicelluloses and remaining two are cellulose and lignin [1]. Xylan is the most abundant hemicellulosic biopolymer and it's constituent about $25 \%$ - 35\% of dry biomass of woody and non woody tissues in different dicots and monocots respectively. The composition of xylans varies in different parts of plant and its structure depends on the source. The backbone in xylans is commonly made up of xylose units which are linked by $\beta-1$,4glycosidic bonds and these structural units are mostly substituted at C-2 and C-3 with different organic compounds like glucuronic acid, acetyl or phenolic group [1] [2].

Xylanases have commercial value in food industry and used in juice clarification. While in poultry, used as a feed for poultry and ruminants. Xylanases are also used in paper and pulp industries, textile and bioconversion of agricultural wastes into fermentative products [3]. Xylanases are normally produced using submerged fermentation, but solid-state fermentation has gained deep interest and attention of researchers due to its high percentage conversion rate biomass to energy conservation, agro-industrial waste treatment and in production of secondary metabolites [4]. In SSF process, the substrate in solid form not only provides the essential nutrients for the growth of microorganism in the culture but it also serves as a support for the microbial cells or body. Enzymes production using agro-industrial waste as substrates under SSF conditions have provided quite a lot of advantages in productivity, cost-effectiveness, time and medium components. In addition to these advantages, it has given some environmental advantages such as less effluents production and waste minimization [5] [6]. Variable optimization for solid state culture medium for xylanase production have been reported very few in the scientific literature [7]. So, the present study was designed to investigate the impact of microbial enzymes for the production of bioethanol by enzymatic scharification of $\beta$-glucosidase, $\beta$-xylosidase and xylanase which are produced from F. fomentarius and culture conditions were optimized by Response Surface Methodology.

\section{Material and Methods}

\subsection{Chemical and Lignocellulosic Substrate}

All the chemicals used in this study were of analytical laboratory grade. The lignocellulosic agricultural wastes such as wheat straw, rice husk, sugarcane bagasse and siris pods were collected from the local market of Gujrat, Pakistan. The substrates were collected, dried and ground into $40 \mathrm{~mm}$ mesh size and finally stored in air tight plastic jars.

\subsection{White Rot Fungus Strain}

A pure culture of locally isolates of $F$. fomentarius culture were multiplied on potato dextrose agar (PDA) slant medium [8] at $\mathrm{pH} 4.5$ and temperature $35^{\circ} \mathrm{C}$.

\subsection{Inoculum Development}

To develop homogeneous fungal spore suspension, $F$. fomentrius was cultivated at $30^{\circ} \mathrm{C} \pm 1{ }^{\circ} \mathrm{C}$ for 5 days in an Erlenmeyer flask $(250 \mathrm{~mL})$ containing a nutritional salt medium. Before fungal inoculation, the medium was sterilized at $121^{\circ} \mathrm{C}$ and $15 \mathrm{l} \mathrm{b} / \mathrm{in}^{2}$ pressure in a laboratory scale and autoclave for $20 \mathrm{~min}$ [9].

\subsection{Screening of Substrate}

Five gram of each four substrates (wheat straw, rice husk, sugarcane bagasse and siris pods) were taken in triplicate flasks and moistened with $10 \mathrm{~mL}$ Vogel's medium and autoclaved. Then inoculated with $3 \mathrm{~mL}$ of freshly prepared fungal spore suspension in sterile condition and incubated at $35^{\circ} \mathrm{C}$ for four days in a still culture incubator.

\subsection{Enzyme Extraction Procedure}

The crude xylanases were extracted by adding $50 \mathrm{~mL}$ of distilled water in solid-state cultures, followed by shaking at $120 \mathrm{rpm}$ for $30 \mathrm{~min}$. Then, experimental mass was passed through Whatman No.1 filter paper and the filtrate was centrifuged at $4^{\circ} \mathrm{C}, 3000 \times \mathrm{g}$ for $10 \mathrm{~min}$ to get clear and biomass cell debris free supernatant. The resulting supernatants were collected and used as a crude enzyme extract for xylanase activity [10]. 


\subsection{Xylanase Activity Assay}

The obtained crude enzyme extract was subjected for estimation of xylanase activity using the UV/Visible spectrophotometric method. The reaction mixture contained $0.5 \mathrm{~mL}$ substrate (1\% oat spelt xylan), $1 \mathrm{~mL}$ of phosphate buffer (pH 6) and $0.5 \mathrm{~mL}$ of enzyme sample. After 30 minutes of reaction time, $2 \mathrm{~mL}$ DNS reagent was added to the test tube containing reaction mixture. Then, it was cool down for five minutes. The produced free xylose units react with DNS reagent and form a colored complex. This colored complex is measured by spectrophotometer at a wavelength of $550 \mathrm{~nm}$. The recorded activities were expressed as $\mathrm{U} / \mathrm{mL}$ while one unit of xylanase activity was defined as the amount of enzyme forming $1 \mu \mathrm{mol}$ of xylose per min [11].

\subsection{Optimization of SSF Parameters}

Maximum production of enzyme required the optimization of different growth conditions. So, classical strategy was adopted for optimization of incubation time, temperature and $\mathrm{pH}$. This was performed by varying one variable at a time in triplicate and maintaining the previously optimized at optimal level. After selection of optimum time period, temperature and $\mathrm{pH}$ five parameters; inoculums size $(2-6 \mathrm{~mL})$, moisture content $(50 \%-80 \%)$, Ammonium sulphate level (50 - $300 \mathrm{mg}$ ), Calcium carbonate (50 - $200 \mathrm{mg}$ ) and glucose level (0.5 - 2 g) were optimized through statistical design like Response Surface Methodology.

\subsection{Optimization of Incubation Period}

Triplicate flasks containing wheat straw (5 g) as substrate was moistened with $10 \mathrm{~mL}$ Vogel's media (pH 5) and after sterilization, inoculated with $F$. fomentarius spores and incubated at $35^{\circ} \mathrm{C}$ for $24 \mathrm{~h}-120 \mathrm{~h}$ under still culture conditions. Triplicate flasks were harvested after every 24 hours.

\subsection{Optimization of Initial $\mathrm{pH}$ of the Medium}

The moistened substrate with adjusted $\mathrm{pH}$ levels ( $\mathrm{pH} 4$ - 8) was sterilized in autoclave and uniformly inoculated and incubated at $35^{\circ} \mathrm{C}$ for optimum fermentation time observed in the time course study.

\subsection{Optimization of Incubation Temperature}

Wheat straw (5 g) was moistened and adjusted to optimum $\mathrm{pH}$ 6. The flasks were autoclaved, inoculated and triplicate sets of flasks were incubated at varying temperatures $\left(25^{\circ} \mathrm{C}-45^{\circ} \mathrm{C}\right)$ for optimum time period in the still culture incubator. The temperature supporting maximum fungal growth was selected as optimum temperature for F. fomentarius.

\subsection{Optimization through RSM}

After selection of optimum time period, temperature and $\mathrm{pH}$ five parameters; inoculums size (2 - $6 \mathrm{~mL})$, moisture content (50\% - 80\%), Ammonium sulphate level (50 - $300 \mathrm{mg}$ ), Calcium carbonate (50 - $200 \mathrm{mg}$ ) and glucose level (0.5 - 2 g) were optimized by Response Surface Methodology.

\subsection{Ammonium Sulphate Precipitation for Xylanase Purification}

The purification of highly produced xylanase was performed by centrifugation at $6000 \times \mathrm{g}$ for $15 \mathrm{~min}$, and supernatant was concentrated by lypholization. Then concentrated active fractions of xylanase were further subjected to ammonium sulfate precipitations at various levels (20\%-90\%) and kept at $4^{\circ} \mathrm{C}$ for 6 hours (h), followed by centrifugation as described above. After centrifugation the pellet was dissolved in buffer and dialyzed to removed salt. The $100 \mathrm{mM}$ phosphate buffer ( $\mathrm{pH} 6$ and pKa 4.7) was used to dissolve the pellets and it was dialyzed against the same buffer after sealing securely in a dialysis bag to remove extra salt and the dialysate was finally freeze dried. Total proteins and xylanase activity were determined before and after ammonium sulphate precipitation and dialysis.

\subsection{Gel Filtration Chromatography}

The active xylanase fractions were loaded on the Sephadex-G-100 column $(2 \times 25 \mathrm{~cm})$ for further purification. 
The $3 \mathrm{~mL}$ of sample in $100 \mathrm{~mL}$ of $50 \mathrm{mM}$ phosphate buffer of $\mathrm{pH} 7$ was used as a elution buffer with flow rate of $1 \mathrm{~mL} / \mathrm{min}$. Up to 20 different active fractions ( $1 \mathrm{~mL}$ each) were collected and monitored for xylanase activity.

\subsection{Determination of Protein Contents}

Bovine serum albumin (BSA) was used as a standard to determine the protein contents of crude and purified xylanase extracts by adopting the spectrophotometric method [8].

\subsection{Protein Estimation}

Quantity of protein was determined by using standard curve made from different known concentration of BSA.

Protein in $\mathrm{mg} / \mathrm{ml}=$ standard factor $\times$ absorbance

Standard factor $=$ slope $\times$ dilution $\times$ volume of sample

\subsection{Optimization of Xylanase through RSM}

After selection of optimum time period, temperature and $\mathrm{pH}$ five parameters; inoculums size (2 - $6 \mathrm{~mL}$ ), moisture content (50\% - 80\%), Ammonium sulphate level (50 - $300 \mathrm{mg}$ ), Calcium carbonate (50 - $200 \mathrm{mg}$ ) and glucose level (0.5 - $2 \mathrm{~g}$ ) were optimized by Response Surface Methodology (RSM).

\subsection{Characterization of Xylanase Enzyme}

The purified active xylanase fractions were subjected to characterization through kinetic studies through studying the effect of $\mathrm{pH}$, temperature and substrate concentration onxylanase activity. Each experiment was performed in triplicate for statistical analysis.

Effect of Substrate Concentration Determination of Kinetic Constants $K_{m}$ and $V_{\max }$

The kinetic constants $K_{\mathrm{m}}$ and $V_{\max }$ were determined spectrophotometrically at $550 \mathrm{~nm}$ by investigating the effect of different concentrations of xylan as assay substrate in $1-5 \mathrm{mM}$ concentration range. The data was plotted to construct Line weaver-Burk plot to find out $\mathrm{V}_{\max }$ and $\mathrm{Km}$ values.

\section{Results and Discussion}

\subsection{Screening of Substrate and Fungal Strain for Xylanases}

After $96 \mathrm{~h}$ of fermentation, the flasks were harvested and clear supernatant was assayed for xylanase activity. Xylanase was revealed maximum activity for $F$. fomentarius and wheat straw as compared to other substrates and A. ornatus and screened for further analysis (Figure 1). Maximum xylanase activity (18.2 $\pm 2 \mathrm{IU} / \mathrm{mL}$ ) was attained when substrates were inoculated with $3 \mathrm{~mL}$ of freshly prepared inoculum of $F$. fomentarius and incubated at $35^{\circ} \mathrm{C}$. A white rot fungus revealed different growth and enzyme activity patterns on different substrates with the addition of some nutrient supplements and results were attained [12].

\subsection{Optimization of Incubation Period on Enzyme Production}

The results indicated that $F$. fomentarius produced maximum xylanase $(15.3 \pm 4 \mathrm{IU} / \mathrm{mL})$ after $72 \mathrm{~h}$ of fermentation while using screened substrate, followed low activity (13.8 $\pm 2 \mathrm{IU} / \mathrm{mL})$ after $96 \mathrm{~h}$ of incubation (Figure 2). As incubation time further increased, the production of xylanase decreased gradually. Our results are concordant to previously study where Aspergillus niger produced maximumxylanase after $72 \mathrm{~h}$ of fermentation [10] while, Aspergillus ochraceus produced maximum enzyme after $144 \mathrm{~h}$ [13].

\subsection{Optimization of $\mathrm{pH}$}

Vogel's media of varying pH (4 - 8) attained maximum xylanase activity $20.3 \pm 3 \mathrm{IU} / \mathrm{mL}$ at pH 6 in SSF media of screened substrate (Figure 3). From the results, it was observed that the enzyme yield increased with an increase in the $\mathrm{pH}$. Fungi are very vulnerable to variation in $\mathrm{pH}$ and rely on chemical composition of substrates and growth media [14]. Our results are nearly similar to previous study where Aspergillus niger showed maximum activity at pH 5.5 [10] while, Colletotrichum graminicola showed maximum activity at pH 5.0 [15]. 


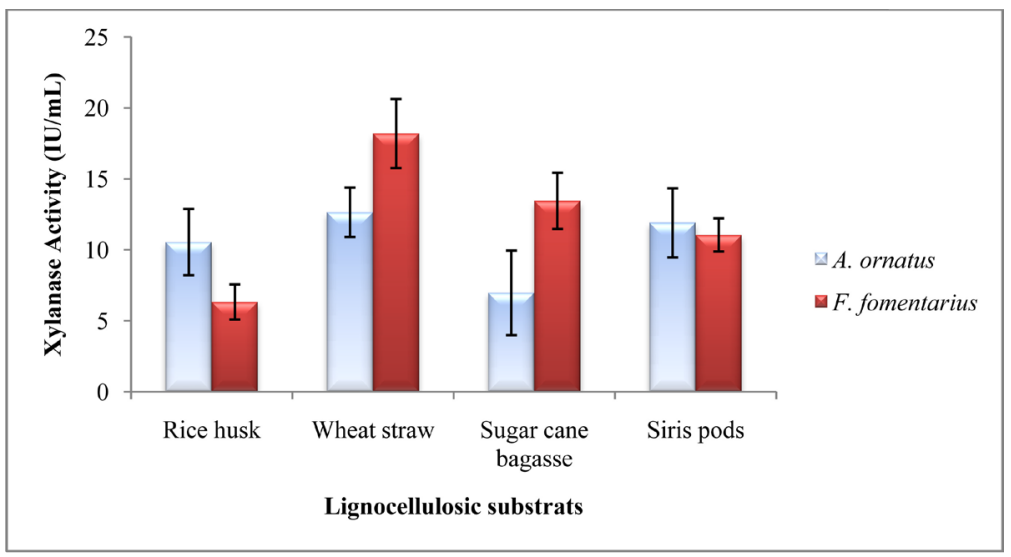

Figure 1. Screening for substrates and fungus.

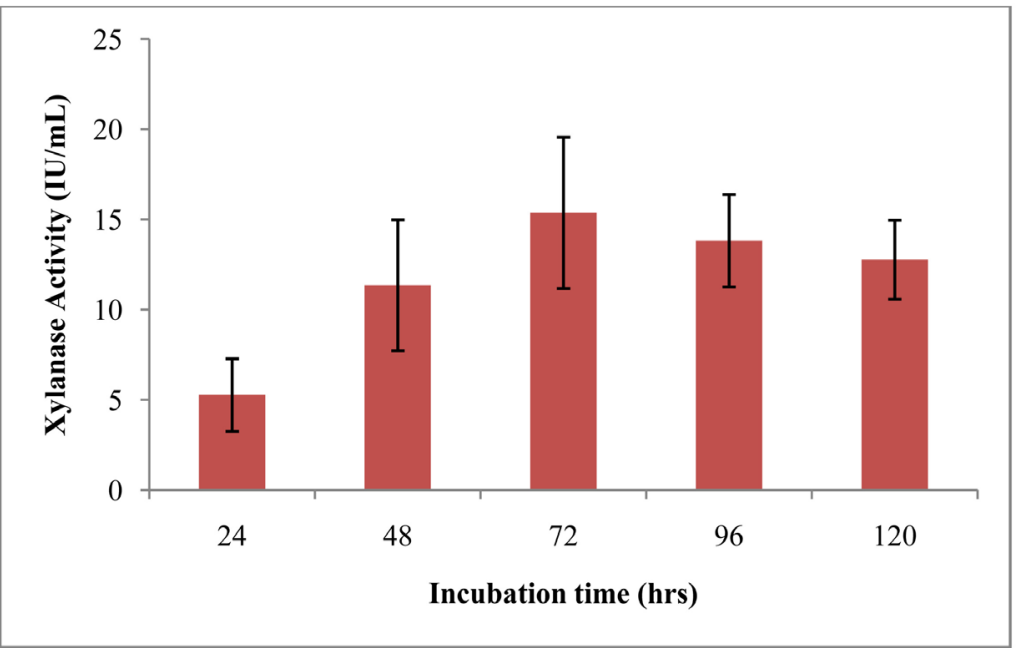

Figure 2. Optimization of incubation period.

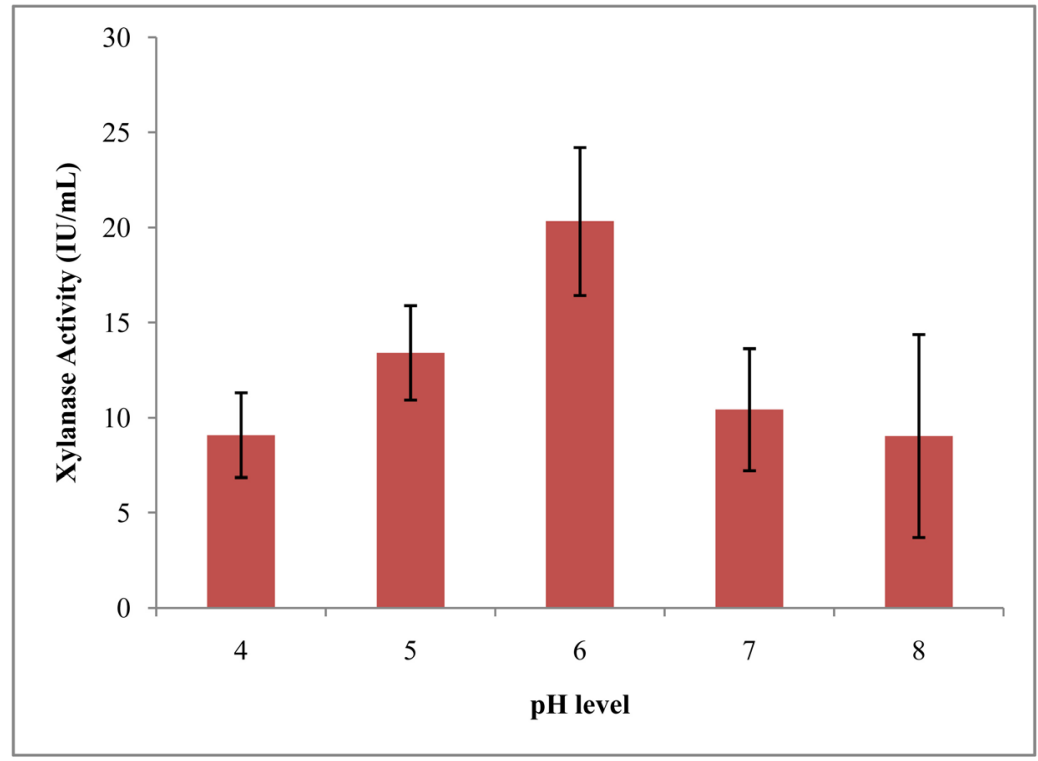

Figure 3. Optimization of $\mathrm{pH}$. 


\subsection{Optimization of Incubation Temperature}

F. fomentarius showed maximum enzyme activity $\left(24.6 \pm 3.3 \mathrm{IU} / \mathrm{mL}\right.$ ) at $30^{\circ} \mathrm{C}$ (Figure 4 ) and when temperature raised above $40^{\circ} \mathrm{C}$, the moisture content of substrate was lost which affected metabolic activities of the fungus and ultimately reduced growth and enzyme production. A variation in incubation temperature had a significant influence on synthesis of ligninolytic enzymes and their activities. The temperatures ranging from $25^{\circ} \mathrm{C}-37^{\circ} \mathrm{C}$ had been found optimum for xylanase production by different microorganisms [14]. Higher temperatures denatured the metabolic enzymes of microorganisms leading to inhibition of growth and enzyme formation [15] [16].

\subsection{RSM Optimized Condition}

After selection of optimum time period, temperature and $\mathrm{pH}$ five parameters; inoculums size, moisture content, Ammonium sulphate level, Calcium carbonate and glucose level were optimized by Response Surface Methodology. The maximum xylanase activity $(146 \pm 8 \mathrm{IU} / \mathrm{mL})$ was observed at $65 \%$ moisture content, $4 \mathrm{~mL}$ inoculums size, 175 g Ammonium sulphate, $200 \mathrm{mg}$ Calcium carbonate and 1.4 grams of glucose (Figures 5-13). Only selected graph were presented in paper along with factors which showed maximum activity of xylanases.

\subsection{Purification of Xylanase}

The crude clear supernatant of enzyme solution was partially purified by ammonium sulfate precipitation. The maximum enzyme $(238.7 \pm 6.2 \mathrm{IU} / \mathrm{mL}$ ) was recovered at $60 \%$ ammonium sulphate and dialysis the activity up to 1.62 fold. After precipitation, further purification was performed by gel filtration chromatography using Sephadex G-100 column. About 20 fractions were collected and maximum activity (322.9 $\pm 12 \mathrm{IU} / \mathrm{m})$ of enzyme was obtained at $80 \%$ of ammonium sulphate concentration and results are similar to Kamble and Jadhav [17]. The xylanase enzyme was purified by gel filtration on Sephacryl S-200 [18], Iqbal et al., [19] also used the gel filtration chromatography for the purification of fungal cellulose (Figure 14).

\subsection{Characterization of $\mathrm{pH}$ on Purified Xylanase}

The optimum $\mathrm{pH}$ of purified xylanase was found to be 6.0 and further rise in $\mathrm{pH}$ was resulted in decreased the activity (Figure 15) and these findings were concordant to previously study in which Aspergillusterreus showedoptimum activity at pH 6 [18], while Chaetomium thermophile was 6.5 [20] and purified xylanase of Paecilomycesthermophila had optimum activity $\mathrm{pH}$ of 7.0. The enzyme was stable over a broad range $\mathrm{pH} 6.0$ - 11.0 [10].

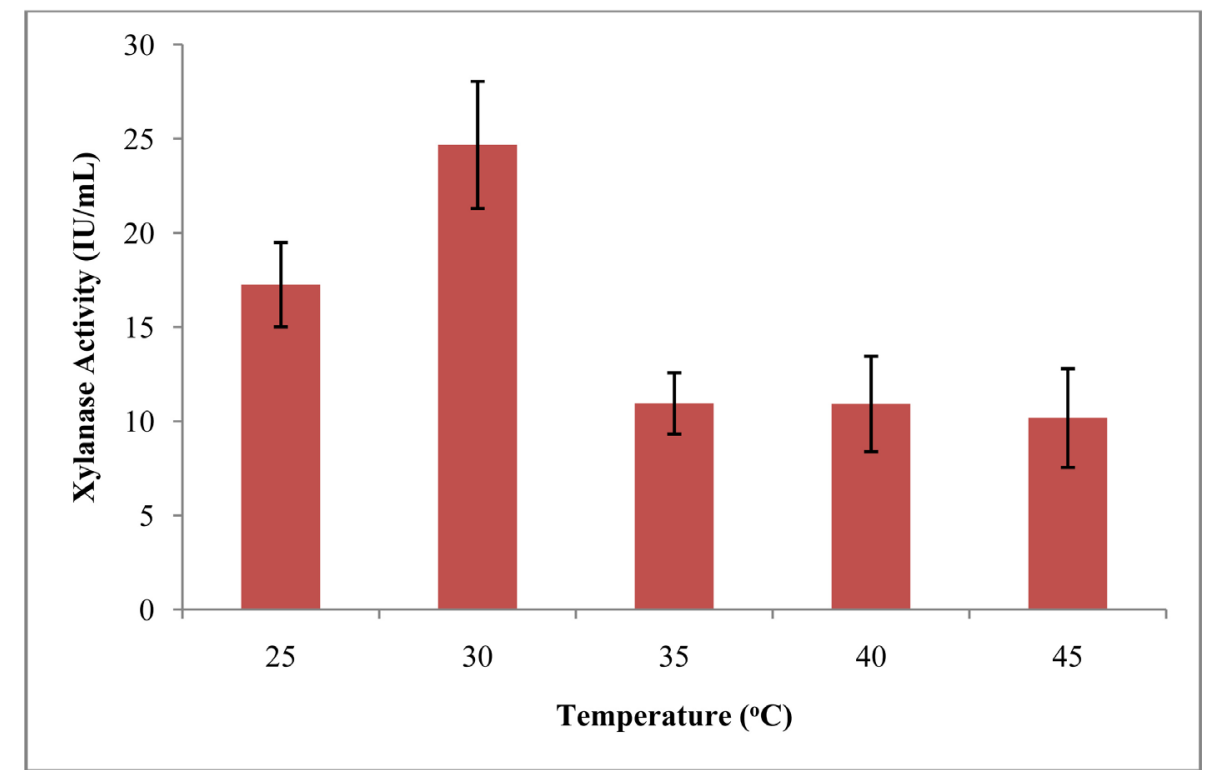

Figure 4. Optimization of temperature. 


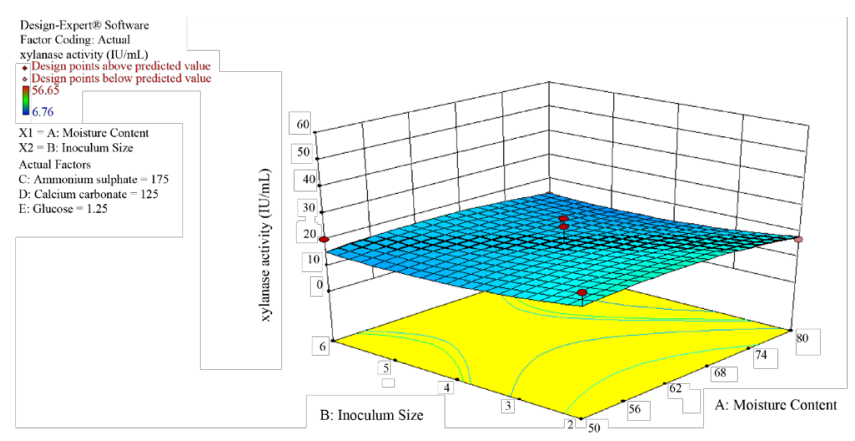

(a)
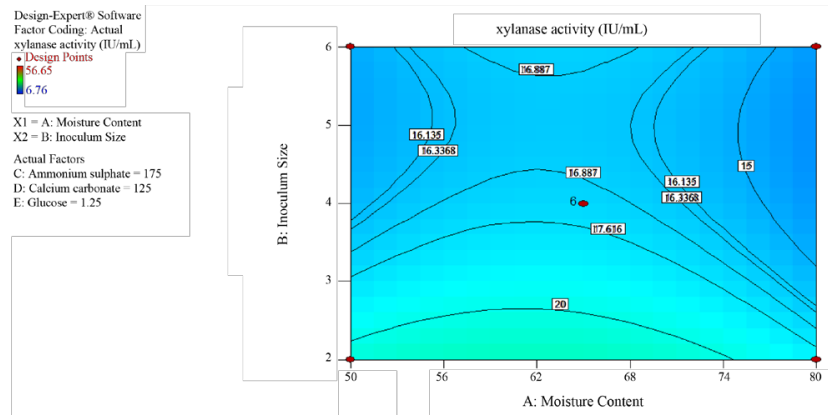

(b)

Figure 5. (a) Response surface plot of xylanase showing the interaction between moisture content and inoculum size; (b) Contour plot of xylanase showing the interaction between moisture content and inoculum size.

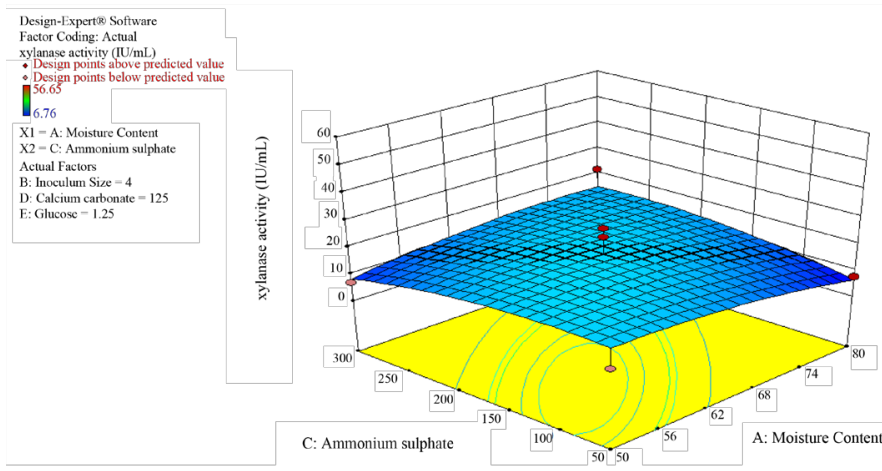

(a)
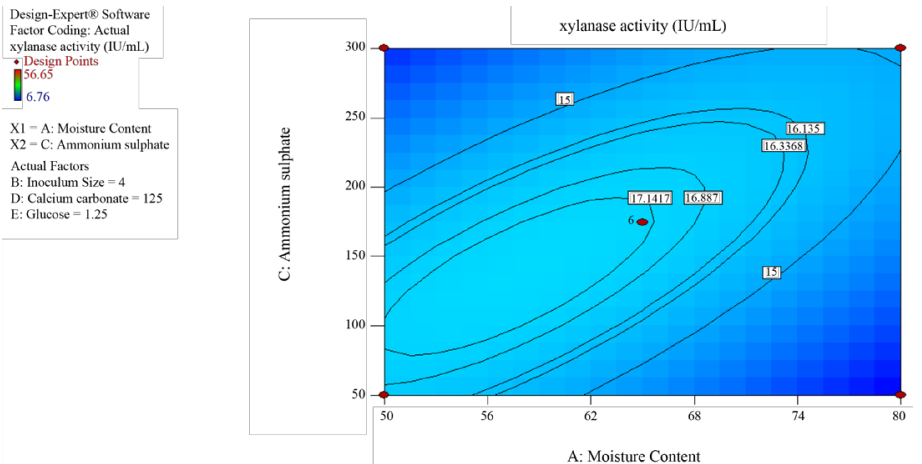

(b)

Figure 6. (a) Response surface plot of xylanase showing the interaction between moisture content and ammonium sulphate; (b) Contour plot of xylanase showing the interaction between moisture content and ammonium sulphate. 


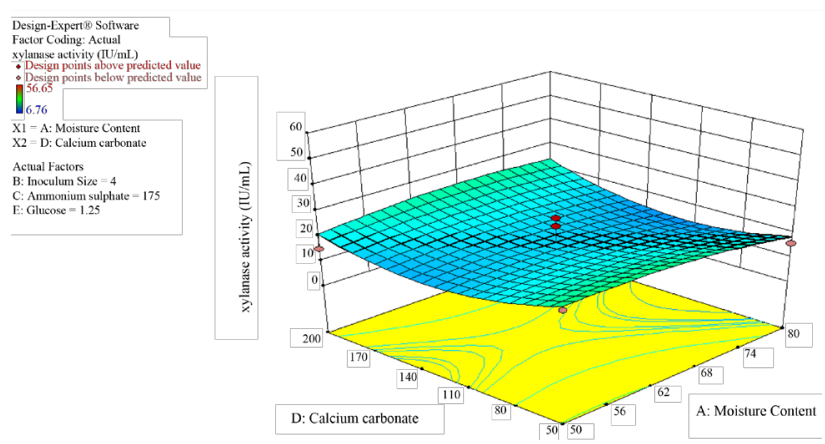

(a)
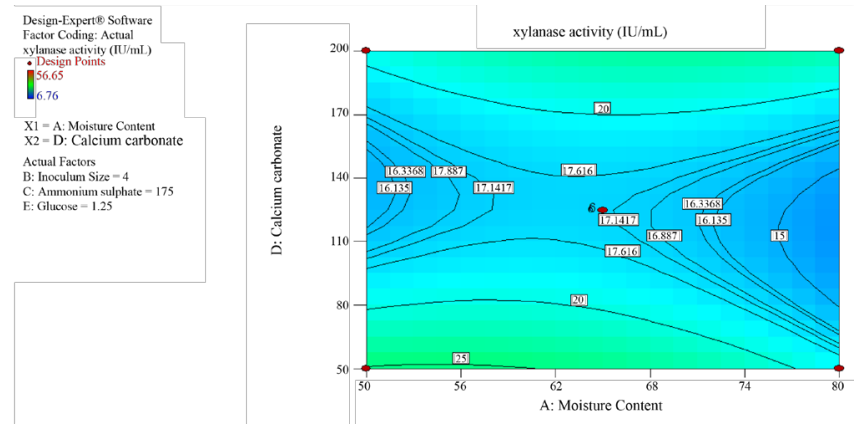

(b)

Figure 7. (a) Response surface plot of xylanase showing the interaction between moisture content and calcium carbonate; (b) Contour plot of xylanase showing the interaction between moisture content and calcium carbonate.
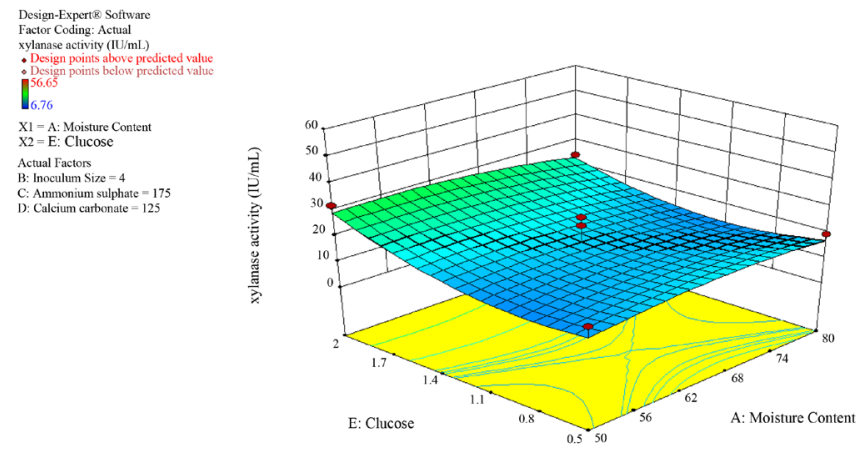

(a)
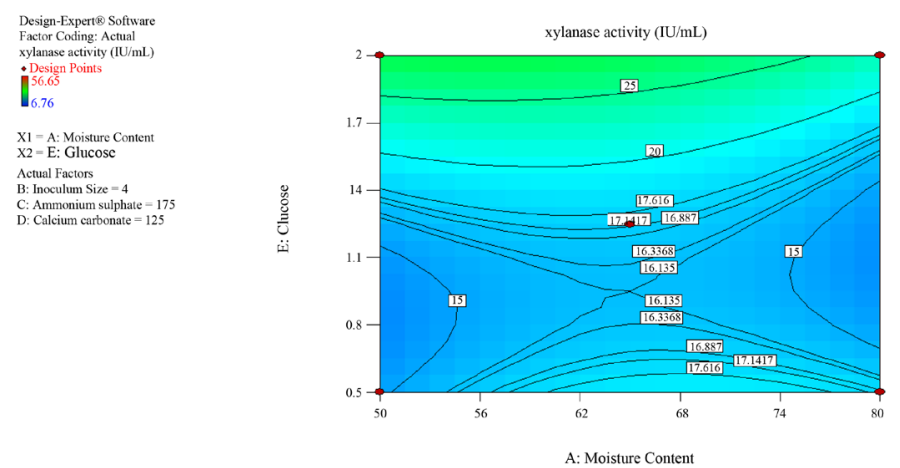

(b)

Figure 8. (a) Response surface plot of xylanase showing the interaction between moisture content and glucose; (b) Contour plot of xylanase showing the interaction between moisture content and glucose. 

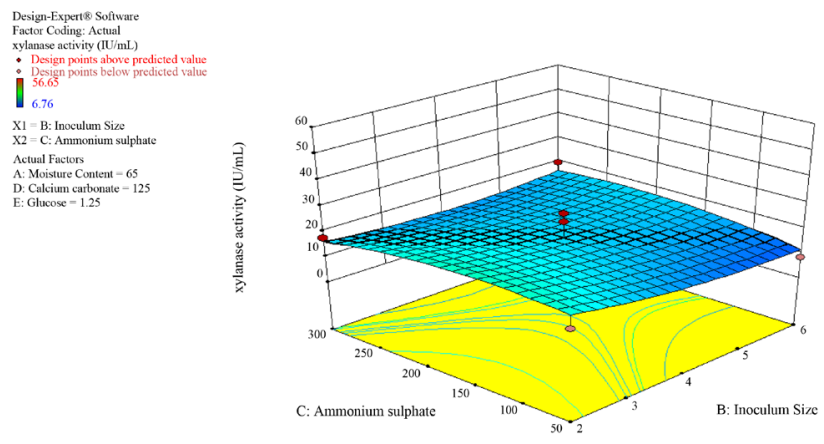

(a)
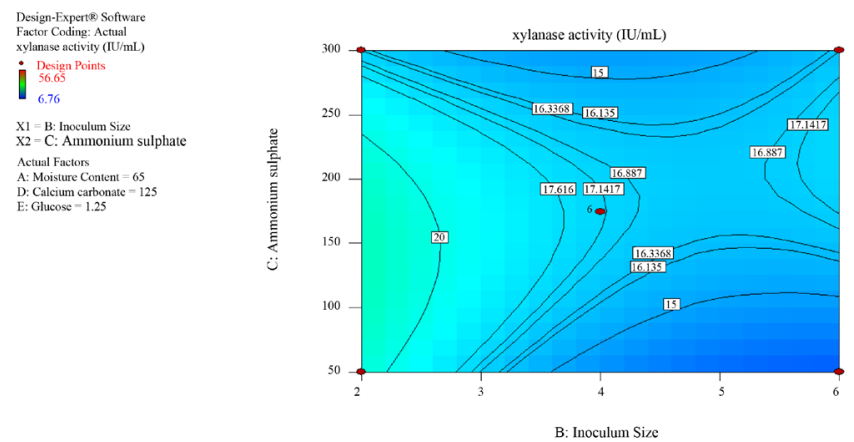

(b)

Figure 9. (a) Response surface plot of xylanase showing the interaction between inoculum size and ammonium sulphate; (b) Contour plot of xylanase showing the Interaction between inoculum size and ammonium sulphate.
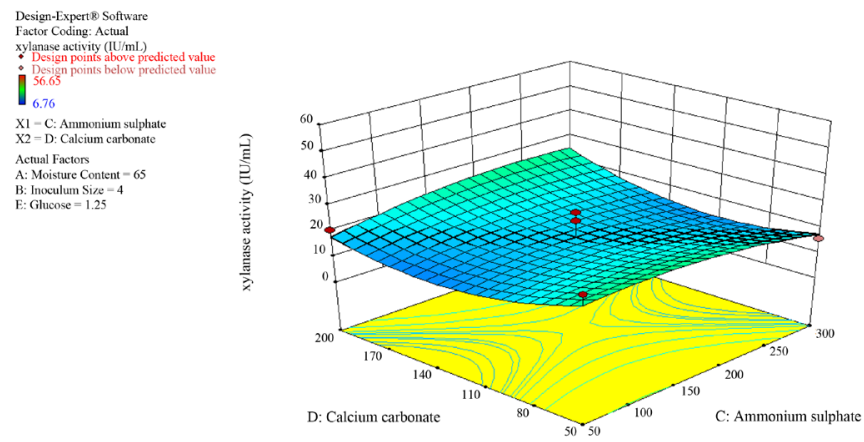

(a)
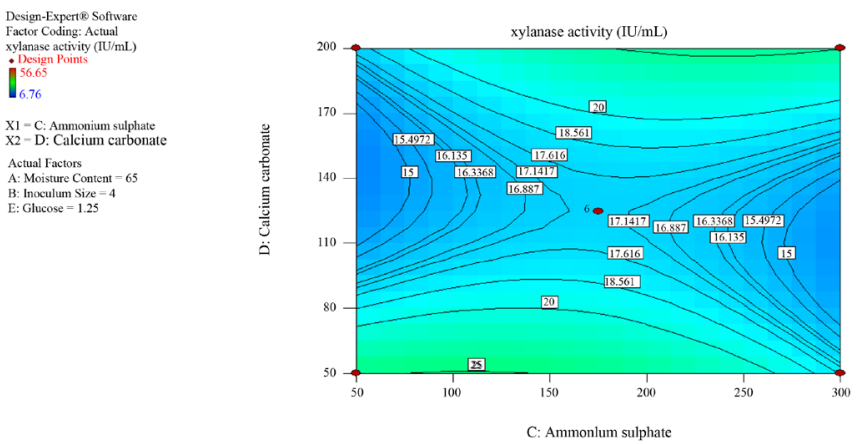

(b)

Figure 10. (a) Response surface plot of xylanase showing the interaction between ammonium sulphate and calcium carbonate; (b) Contour plot of xylanase showing the interaction between ammonium sulphate and calcium carbonate. 

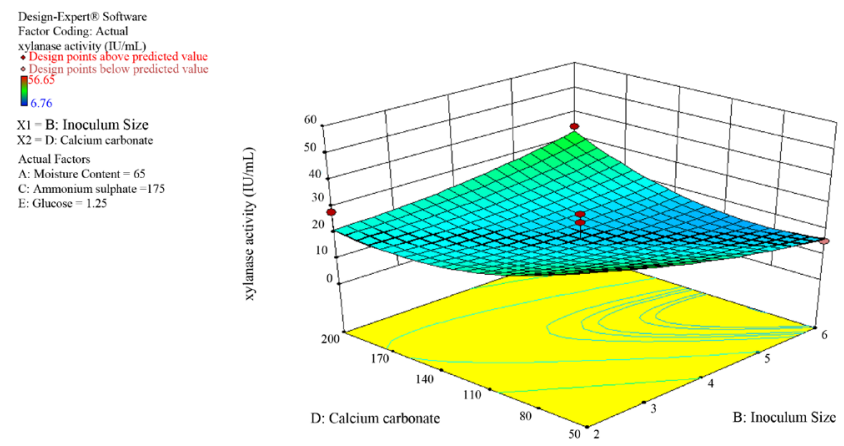

(a)
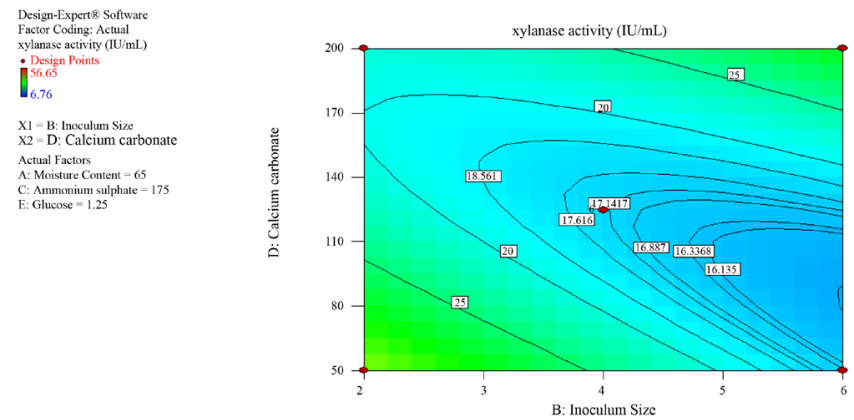

(b)

Figure 11. (a) Response surface plot of xylanase showing the interaction between inoculums size and calcium carbonate; (b) contour plot of xylanase showing the interaction between inoculums size and calcium carbonate.
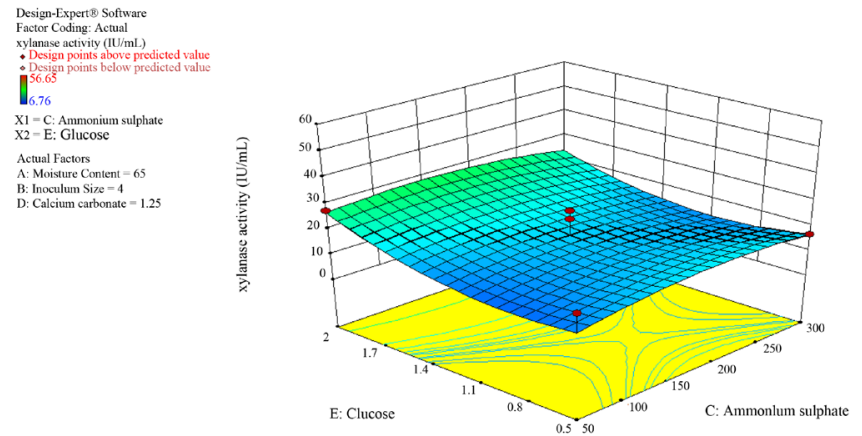

(a)
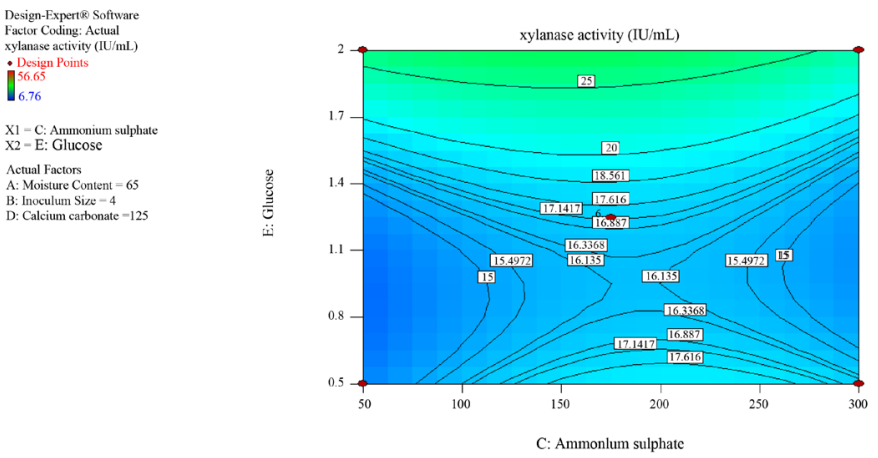

(b)

Figure 12. (a) Response surface plot of xylanase showing the Interaction between ammonium sulphate and glucose; (b) Response surface plot of xylanase showing the interaction between ammonium sulphate and glucose. 
Design-Expert ${ }^{2}$ Software

Factor Coding: Actual

xylanase activity $(\mathrm{IU} / \mathrm{mL})$

- Design points above predicted valu

predicted value

$\coprod_{6.76}^{56.65}$

$\mathrm{Xl}=\mathrm{D}$ : Calcium carbonate

$\mathrm{X} 2=\mathrm{E}:$ Glucose

Actual Factors

A: Moisture Content $=65$

: .

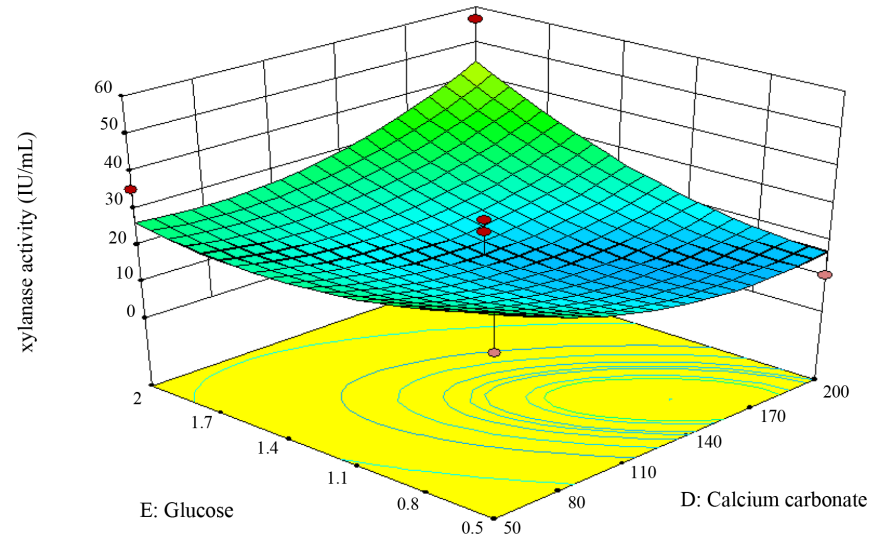

(a)

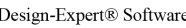

Factor Coding: Actual

xylanase activity $(\mathrm{IU} / \mathrm{mL})$

- Design Point

6.76

$\mathrm{Xl}=\mathrm{D}:$ Calcium carbonat

$\mathrm{X} 2=\mathrm{E}$ : Glucose

Actual Factors

A: Moisture Content $=65$

B: Inoculum Size $=4$

C: Ammonium sulphate $=175$

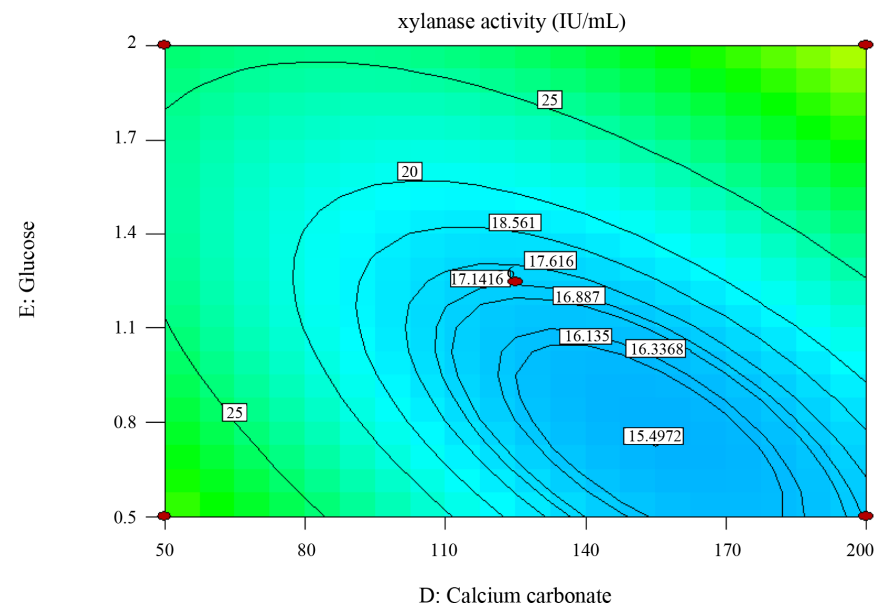

(b)

Figure 13. (a) Response surface plot of xylanase showing the interaction between calcium carbonate and glucose; (b) Response surface plot of xylanase showing the Interaction between calcium carbonate and glucose.

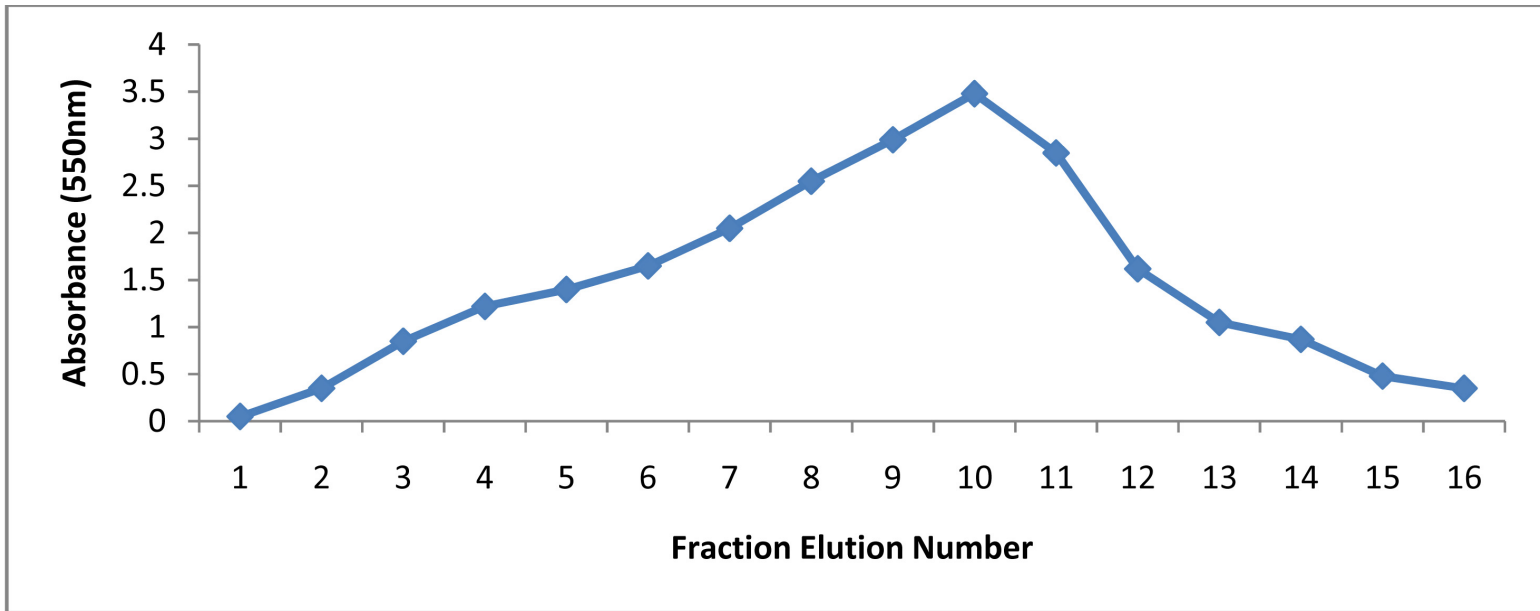

Figure 14. Gel filtration chromatography of xylanase from Fomes fomentarius. 


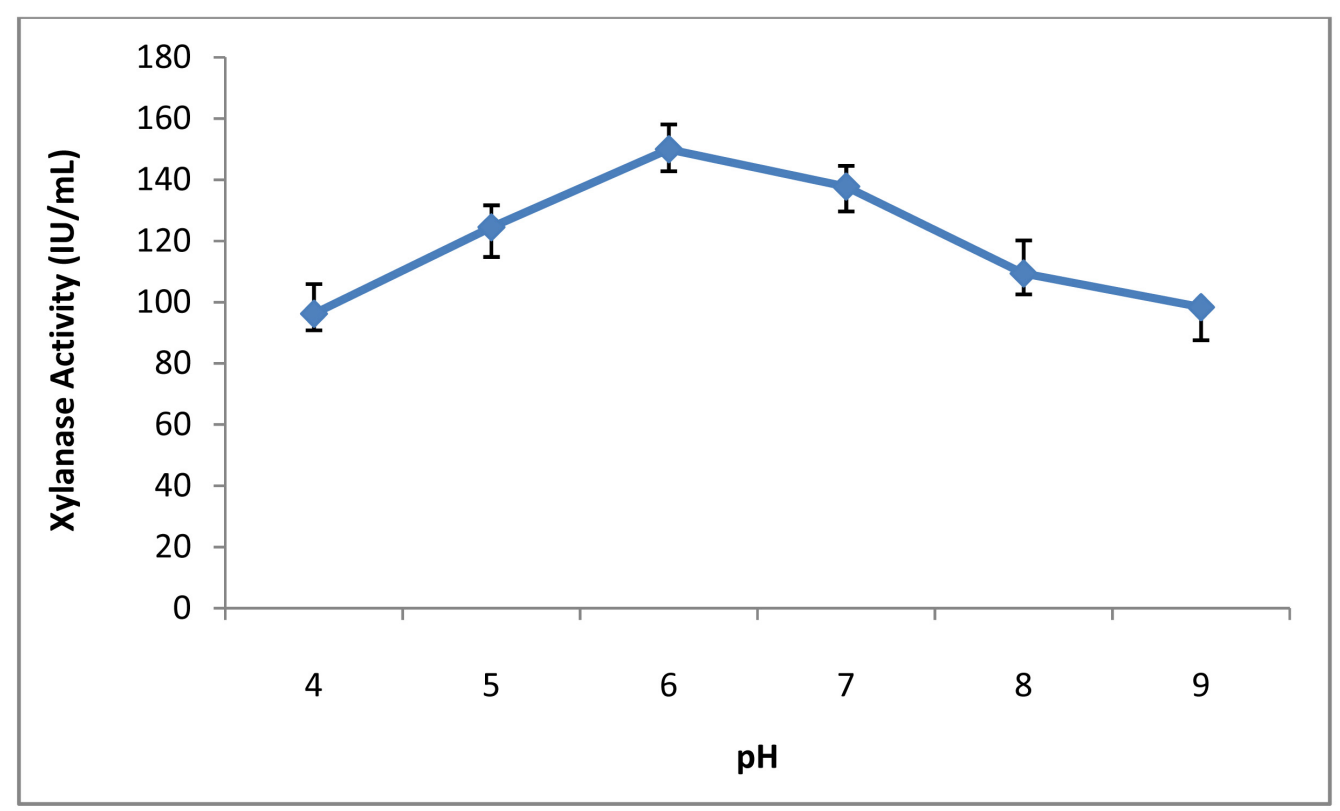

Figure 15. Effect of different $\mathrm{pH}$ on xylanase activity.

\subsection{Characterization of Temperature on Purified Xylanase}

Thethermo-stability of the purified xylanase was investigated by measuring enzyme activity at different temperatures and optimum temperature for purified xylanase was $40^{\circ} \mathrm{C}$ (Figure 16). An initial increase in temperature increased the xylanase activity by enhancing the kinetic energy of the molecules and increasing the interaction between enzyme active site and interacting groups of the substrate. Enzymes produced from different microorganisms had been reported to show optimum activities in the temperature range of $40^{\circ} \mathrm{C}$ to $65^{\circ} \mathrm{C}$ [16] [21]. Xylanase from Colletotrichumgraminicola had maximum activity at $65^{\circ} \mathrm{C}[15]$ and optimum temperature was $70^{\circ} \mathrm{C}$ for xylanase produced by Chaetomiumthermophilus (18 Latif et al., 2006).

\subsection{Determination of Kinetic Constants $K_{M}$ and $V_{\max }$}

The Line-weaver Burk was plotted against the reciprocal of substrate concentration (1/[S] and reciprocal of velocity of reaction to attain $\mathrm{Km}$ and $V_{\max }$ values. The values of kinetic parameters $K_{M}$ and $V_{\max }$ for purified xylanase were $1.25 \mathrm{mM}$ and $54 \mathrm{mM} / \mathrm{min}$, respectively, using xylan as a substrate (Figure 17). The relationship between rate of reaction and concentration of substrate depends on the affinity of the enzyme for its substrate expressed as $K_{M}$ (Michaelis constant) of the enzyme. Very low value of $K_{M}$ and high $V_{\max }$ revealed that xylanase reflected its higher affinity for xylan and high catalytic efficiency as compared to a xylanase from other fungi. The xylanase of Aspergillus terreus showed $\mathrm{Km} 3.57 \mathrm{mg} / \mathrm{ml}$ and Vmax $55.5 \mathrm{~mol} / \mathrm{min}$ per $\mathrm{mg}$ [18] and xylanase from Bacillus gave $\mathrm{Km} 5.26 \mathrm{mg} / \mathrm{mL}$ and $V_{\max } 277.7 \mu \mathrm{mol} / \mathrm{min} / \mathrm{mg}$ for birch wood xylan as a substrate [17].

\section{Conclusion}

F. fomentarius showed maximum xylanase activity $146 \pm 8 \mathrm{IU} / \mathrm{mL}$ when grown on wheat straw in solid state fermentation incubation time of $72 \mathrm{~h}, \mathrm{pH} 6.0$ and temperature of $30^{\circ} \mathrm{C}$ and optimized parameter through Response Surface Methodology (RSM) in Central Composite Statistical Design observed that the maximum xylanase activity was observed at 65\% moisture content, $4 \mathrm{~mL}$ inoculums size, $175 \mathrm{mg}$ Ammonium sulphate, 200 mg Calcium carbonate and 1.4 grams of glucose. After purification with $\left(\mathrm{NH}_{4}\right)_{2} \mathrm{SO}_{4}$, dialysis and Sephadex G-100 gel filtration chromatography the activity of enzyme increased up to 2.2 fold. Kinetic study revealed that recently produced xylanase was the cheaper enzyme which had industrial applications. Presently produced enzymes are potentially important for feed, candies, paper and pulp industry. This indigenously prepared enzyme is not only fulfilling the need of industry, it can also reduce the reliance of imported enzymes. 


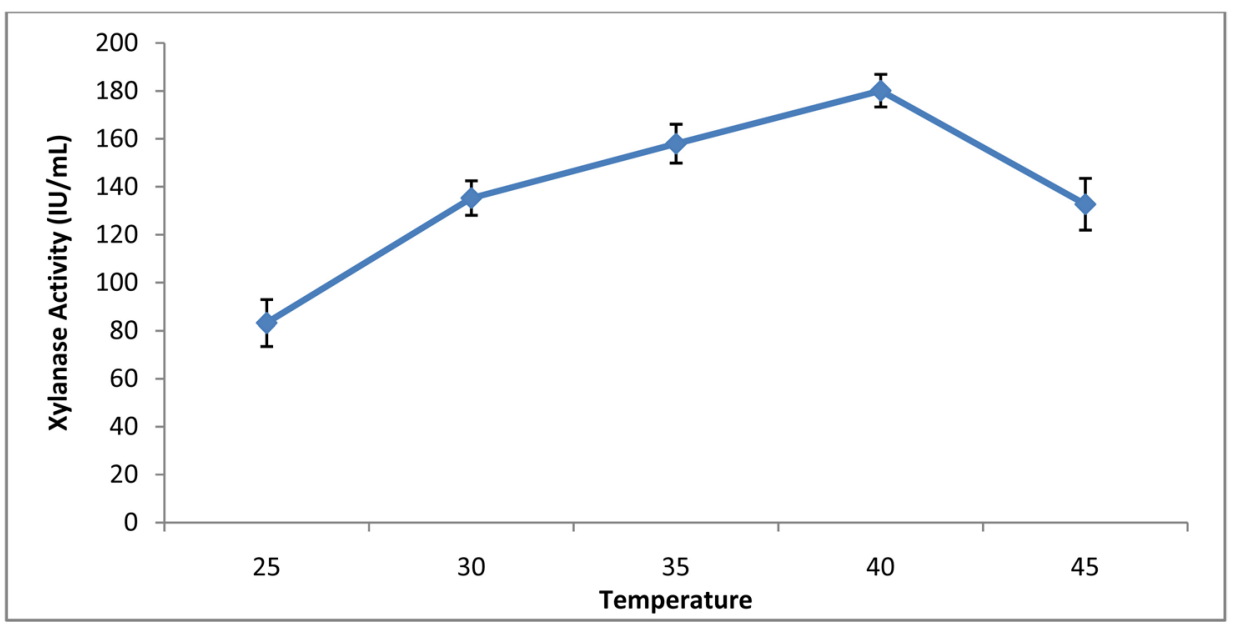

Figure 16. Effect of different temperatures on activity of xylanase.

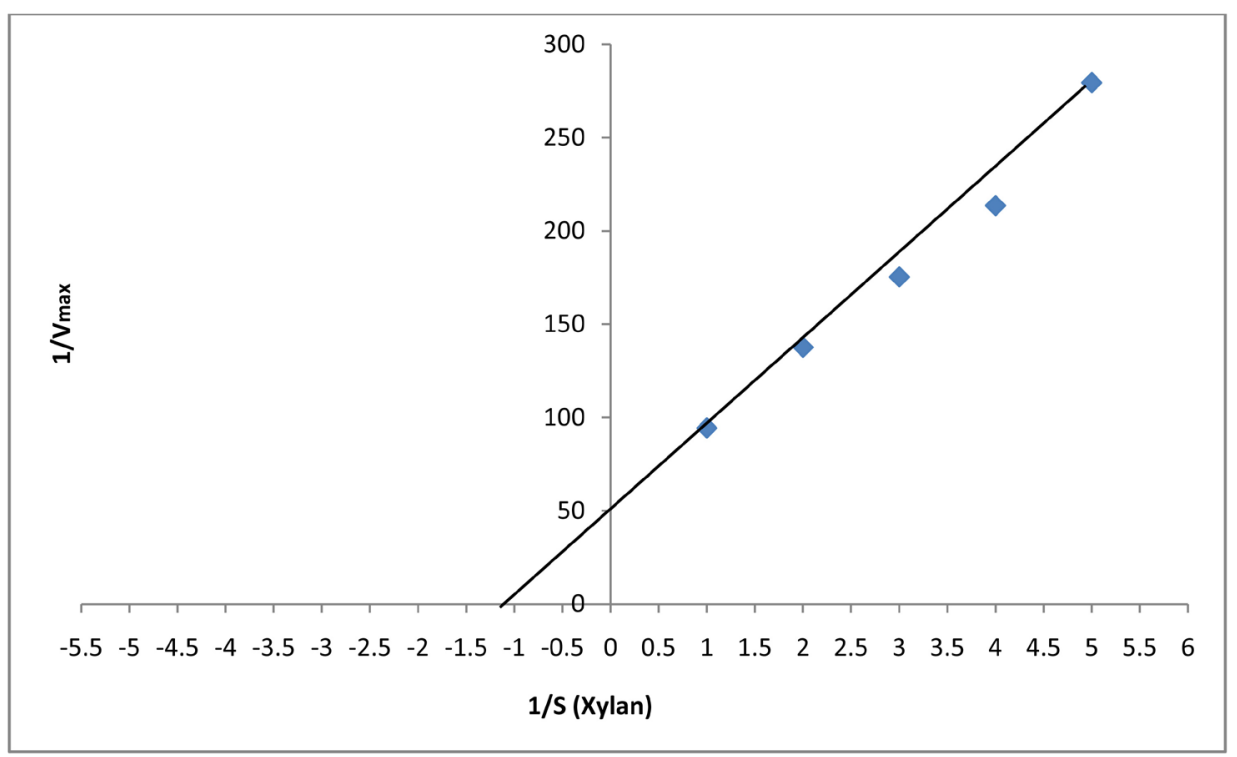

Figure 17. Reciprocal plot of $1 /[\mathrm{S}]$ Vs $1 /[\mathrm{V}]$ for determination of $K_{M}$ and $V_{\max }$ of xylanase produced by $F$. fomentarius.

\section{Acknowledgements}

Author is highly thankful to the HEC funded project of NRPU/R\&D/HEC/14/761 "Hyper production of commercial Cellulases from Indigenously isolated Fungi and screening of Local Agro-industrial wastes” for financial support.

\section{Conflict of Interest}

Authors have no conflict of interest with any scientist or department.

\section{References}

[1] Wong, K.K.Y., Tan, L.U.L. and Saddler, J.N. (1988) Multiplicity of $\beta$-1,4xylanase in Microorganisms: Functions and Applications. Microbiology Reviews, 52, 305-317.

[2] Moure, A., Gullón, P., Domínguez, H. and Parajó, J.C. (2006) Advances in the Manufacture, Purification and Applications of Xylo-Oligosaccharides as Food Additives and Nutraceuticals. Process Biochemistry, 41, 1913-1923. 
http://dx.doi.org/10.1016/j.procbio.2006.05.011

[3] Subramaniyan, S. and Prema, P. (2002) Biotechnology of Microbial Xylanases: Enzymology, Molecular Biology, and Application. Critical Reviews in Biotechnology, 22, 33-64. http://dx.doi.org/10.1080/07388550290789450

[4] Kaushal, R., Sharma, N. and Tandon, D. (2012) Cellulase and Xylanase Production by Co-Culture of Aspergillus niger and Fusarium oxysporum Utilizing Forest Waste. Turk. J. Biochem., 37, 35-41. http://dx.doi.org/10.5505/tjb.2012.43434

[5] Pandey, A. (2003) Solid-State Fermentation. Biochemical Engineering Journal, 13, 81-84. http://dx.doi.org/10.1016/S1369-703X(02)00121-3

[6] Couto, S.R. and Sanromán, M.A. (2006) Application of Solid-State Fermentation to Food Industry a Review. Journal of Food Engineering, 76, 291-302. http://dx.doi.org/10.1016/j.jfoodeng.2005.05.022

[7] Levin, L., Herrmann, C. and Papinutti, V.L. (2008) Optimization of Lignocellulolytic Enzyme Production by the White-Rot Fungus Trametestrogii in Solid-State Fermentation Using Response Surface Methodology. Biochemical Engineering Journal, 39, 207-214. http://dx.doi.org/10.1016/j.bej.2007.09.004

[8] Imran M., Asad, M.J., Gulfraz, M., Qureshi, R., Gul, H., Manzoor, N. and Choudhary, N.A. (2012) Glucoamylase Production from Aspergillus niger by Using Solid State Fermentation Process. Pakistan Journal of Botany, 44, 21032110 .

[9] Amir, I., Anwar, Z., Zafar, Y., Iqbal, H., Aish, M., Muhammad, I. and Sajid, M. (2011) Optimization of Cellulase Enzyme Production from Corn Cobs Using Alternaria alternata by Solid State Fermentation. Journal of Cell and Molecular Biology, 9, 51-56.

[10] Ahmad, Z., Butt, M.S., Ahmed, A., Riaz, M., Sabir, S.M., Farooq, U. and Rehman, F. (2014) Effect of Aspergillus niger xylanase on Dough Characteristics and Bread Quality Attributes. Journal of Food Science and Technology, 51, 2445-2453. http://dx.doi.org/10.1007/s13197-012-0734-8

[11] Miller, G.L. (1959) Use of Dinitrosalisylic Acid (DNS) for Determination of Reducing Sugars. Analytical Chemistry, 31, 426-428. http://dx.doi.org/10.1021/ac60147a030

[12] Neifar, M., Kamoun, A., Jaouani, A., Ellouze-Ghorbel, R. and Ellouze-Chaabouni, S. (2011) Application of Asymetrical and Hoke Designs for Optimization of Laccase Production by the White-Rot Fungus Fomes fomentarius in SolidState Fermentation. Enzyme Research, 2011, Article ID: 368525.

[13] Michelin, M., Peixoto-Nogueira, S.C., Betini, J.H., da Silva, T.M., Jorge, J.A., Terenzi, H.F. and Polizeli, M.L.T.M. (2010) Production and Properties of Xylanases from Aspergillus terricola Marchal and Aspergillus ochraceus and Their Use in Cellulose Pulp Bleaching. Bioprocess and Biosystems Engineering, 33, 813-821. http://dx.doi.org/10.1007/s00449-009-0403-0

[14] Asgher, M., Irshad, M. and Iqbal, H.M.N. (2012) Purification and Characterization of Novel Manganese per Oxidase from Shizophyllum Commune IBL-06. International Journal of Agriculture and Biology, 15, 749-754.

[15] Zimbardi, A.L.R.L., Sehn, C., Meleiro, L.P., Souza, F.H.M., Masui, D.C., Nozawa, M.S.F., Guimarães, L.H.S., Jorge, J.A. and Furriel, R.P.M. (2013) Optimization of $\beta$-Glucosidase, $\beta$-Xylosidase and Xylanase Production by Colletotrichum graminicola under Solid-State Fermentation and Application in Raw Sugarcane Trash Saccharification. International Journal of Molecular Sciences, 14, 2875-2902. http://dx.doi.org/10.3390/ijms14022875

[16] Collins, T., Gerday, C. and Feller, G. (2005) Xylanases, Xylanase Families and Extremophilicxylanases. FEMS Microbiology Reviews, 29, 3-23. http://dx.doi.org/10.1016/j.femsre.2004.06.005

[17] Kamble, R.D. and Jadhav, A.R. (2012) Isolation, Purification, and Characterization of Xylanase Produced by a New Species of Bacillus in Solid State Fermentation. International Journal of Microbiology, 2012, Article ID: 683193.

[18] Chidi, S.B., Godana, B., Ncube, I., Van Rensburg, E.J., Cronshaw, A. and Abotsi, E.K. (2008) Production, Purification and Characterization of Celullase-Free Xylanase from Aspergillus terreus UL 4209. African Journal of Biotechnology, 7, 3939-3948.

[19] Iqbal, H.M.N., Asgher, M. and Bhatti, H.N. (2011) Optimization of Physical and Nutritional Factors for Synthesis of Lignin Degrading Enzymes by a Novel Strain of Trametes versicolor. BioResources, 6, 1273-1278.

[20] Latif, F., Asgher, M., Saleem, R., Akrem, A. and Legge, R.L. (2006) Purification and Characterization of a Xylanase Produced by Chaetomium thermophile NIBGE. World Journal of Microbiology and Biotechnology, 22, 45-50. http://dx.doi.org/10.1007/s11274-005-5745-4

[21] Liu, C., Sun, Z.T., Du, J.H. and Wang, J. (2008) Response Surface Optimization of Fermentation Conditions for Producing Xylanase by Aspergillus niger SL-05. Journal of Industrial Microbiology \& Biotechnology, 35, 703-711. http://dx.doi.org/10.1007/s10295-008-0330-0 